HUL YCH Mariia - Candidate of Pedagogical Sciences, Senior Lecturer at the Department of Comparative Pedagogy and Methodology of Teaching Foreign Languages, Drohobych Ivan Franko State Pedagogical University, 24, Ivan Franko str., Drohobych, 82100, Ukraine

ORCID: https://orchid.org/0000-0002-3447-9131

ResearcherID: https://publons.com/researcher/4409358/maria-hulych/

DOI: https://doi.org/10.24919/2413-2039.12/44.6

To cite this article: Hulych, M. (2021) Polikulturna osvita v Ukraini v konteksti rozvytku osobystosti pedahoha [Polycultural education in Ukraine in the context of the teacher's personality development]. Human Studies. Series of Pedagogy, 12 (11), 46-50, doi: https://doi.org/10.24919/2413-2039.12/44.6

\title{
POLYCULTURAL EDUCATION IN UKRAINE IN THE CONTEXT OF THE TEACHER'S PERSONALITY DEVELOPMENT
}

Summary. The article analyses the conceptual foundations of polycultural education from a pedagogical point of view and determines the peculiarities of polycultural education which is certainly a priority taking into consideration the fact that Ukraine is a multiethnic country. The main legislative acts that confirm the existence of the concept of "multicultural education" have been investigated.

The author reflects on the use of different terminological concepts to illustrate the diversity of ideas regarding the purpose, nature and content of polycultural education and training in a multicultural world.

The term "polycultural education" is understood in the same way as "multicultural education". The proper analysis of the scientific literature has proved that there is no unequivocal opinion concerning the above-mentioned definition, and. accordingly, there is a number of synonyms determining the concept of multicultural education, in particular intercultural and cross-cultural education.

The theory and practice of polycultural education is based on historical, cultural, sociolinguistic, social and pedagogical factors. Modern conditions for the society development make new incresed demands on the competitiveness of future professionals including the ability and readiness to implement the educational process on the basis of multicultural education ideas.

The main principles for the development of multiculturalism in higher education institutions are highlighted, the important tasks ensuring the implementation of the multicultural education ideas for the students' upbringing are outlined. It is noted that a prominent place in the formation of a multicultural personality of the teacher is undoubtedly the study of a foreign language, as language and culture are always in inseparable and productive interaction.

Nevertheless, the development of a multicultural personality is considered as an important task in preparing the younger generation to living harmoniously in the multicultural society.

Key words: polycultural approach, professional training, multicultural society, ethnic groups, personality development.

ГУЛИЧ Марія - кандидат педагогічних наук, доиент кафедри порівняльної педагогіки та методики викладання іноземних мов, Дрогобичький державний педагогічний університет імені Івана Франка, вул. Івана Франка, 24, м. Дрогобич, 82100, Україна

ORCID: https://orchid.org/0000-0002-3447-9131

ResearcherID: https://publons.com/researcher/4409358/maria-hulych/

DOI: https://doi.org/10.24919/2413-2039.12/44.6

Бібліографічний опис статті: Гулич, М. (2021) Полікультурна освіта в україні в контексті розвитку особистості педагога. Людинознавчі студї. Серія «Педагогіка», 12 (11), 46-50, doi: https://doi.org/10.24919/2413-2039.12/44.6

\section{ПОЛІКУЛЬТУРНА ОСВІТА В УКРАЇНІ В КОНТЕКСТІ РОЗВИТКУ ОСОБИСТОСТІ ПЕДАГОГА}

\begin{abstract}
Анотація. У статті проаналізовано концептуальні основи полікультурної освіти з педагогічної точки зору та визначено особливості даного феномену, що вочевидь є пріоритетним напрямом з огляду на те, щзо Україна є багатоетнічною державою. Виокремлено ключові законодавчі
\end{abstract}


акти, щуо служать правовою основою існування власне самого поняття «полікультурна освіта».

Авторка розмірковує про використання різних термінологічних конщепиій для ілюстраиії різноманітності ідей щодо мети, характеру та змісту полікультурної освіти, а також навчання і виховання молоді в полікультурному світі.

Термін «полікультурна освіта» у дослідженні ототожнюється із поняттям «мультикультурна освіта». Зокрема, зазначається, що у науковому дискрсі немає одностайності щуодо трактування даної дефініиії, $і$ відповідно, існує низка синонімічних понять, що детермінують поняття полікультурної освіти, а саме інтеркультурна та кроскультурна освіта.

Теорія та практика полікультурної освіти базується на історичних, культурних, соціолінгвістичних, сочіальних та педагогічних факторах. Сучасні умови розвитку суспільства висувають нові вимоги до конкурентноспроможності майбутніх фахівців, однією з яких $\epsilon$ здатність до здійснення освітнього процесу з опорою на ідеї полікультурної освіти.

Виокремлено основні принщиии, необхідні для розвитку полікультурності у закладах вищої освіти, а також окреслено важливі завдання, виконання яких забезпечить втілення ідей полікультурного навчання та виховання студентської молоді. Зазначено, щзо чільне місие у формуванні полікультурної особистості педагога займає, безсумнівно, вивчення іноземної мови, оскільки мова та культура повсякчас перебувають у нерозривній та продуктивній взаємодії.

У изьому контексті є иілком логічним, щзо розвиток полікультурної особистості майбутьнього фахівия розглядається у дослідженні як важливе завдання підготовки молодого покоління до гармонійного життя у полікультурному суспільстві.

Ключові слова: полікультурний підхід, професійна підготовка, полікультурне супільство, етнічні групи, особистісний розвиток.

Introduction. In our mobile rapidly changing world intensive and constant migration and integration processes have led to complex challenges, including the task of effective implementation of the aids of cultural education. It has become much more relevant, determining a promising strategy for the further development of modern civilization.

The tendencies in social, cultural, economic and political areas of life led to the formation of a multicultural society. Multicultural society is an educational space in which students of different ethnic and linguistic, religious, social and economic affiliations can peacefully live and study.

At the current moment multicultural education is recognized as an educational activity for all European citizens aiming at their socio-cultural integration into a new multilingual and multicultural society, which means that teachers must be able to encourage the students' tolerant attitude to ethnic and cultural differences of the people, as the way of intellectual, linguistic and spiritual enrichment of the individual by finding common roots, establishing intercultural interaction and cooperation.

Hence multicultural education directs its own efforts into the young generation to make them acquire the key competencies related to life in the changing multilingual and multicultural society, the creation of equal opportunities for access to educational resources for young people who come not only from national minorities and various ethnic groups, but also for migrants, refugees without any prejudice and stereotypes.

Analysis of recent publications. The term "multicultural education" was formed in the 1970s. The first attempts to define the concept were made in the International Pedagogical Dictionary. The multicultural education is presented here as a reflection of the ideals of cultural pluralism in education (Intenational Dictionary of Education, 1977).

In the 1990s the International Encyclopedia of Education gave the following interpretation of the term "multicultural education": "it is the pedagogical process in which two or more cultures differing in language, ethnicity, nationality or race are presented" (the International Encyclopedia of Education, 1994).

A more detailed interpretation of multiculturalism can be found in the British Handbook of Cultural Communication Theory. This term defines a society that contains many different but interdependent cultural traditions, often associated with different ethnic components of this society.

The phenomenon of polycultural education and competence is closely associated with the crosscultural and intercultural one.

The English scientist E. Taylor interprets the concept of "intercultural competence" as a transformational process during which a person develops adaptive ability, changing his lifestyle to 
effectively understand and adapt to the requirements of another culture. In this sense, intercultural competence is not the result, but is seen as a constant internal personal process. From this point of view, a person with established intercultural competence is one who has developed behavioral, cognitive and affective (emotional) competencies, such as empathy, adaptive motivation, the ability to seek alternative ways of development, flexibility and skills of personality-oriented approach (Taylor, 1994).

The other scientists offer models of transformation of the educational environment to create the appropriate conditions for successful multicultural learning, in particular: establishing a high level of expectations from students; use of learning style that corresponds to the socio-cultural characteristics of students; development of a relevant curriculum; introduction of role-playing games that motivate the dialogue of cultures (Nieto, 2000).

In the recent years, the Ukrainian scientists have increasingly started to discuss the importance of multicultural aspects in the student"s environment (I. Sokolova, V. Pogrebnyak, M. Leshchenko).

The purpose of the article is to analyze the concept of the multicultural education and reveal its chief aspects in Ukraine.

Presentation of the main material. University education at the beginning of the twenty-first century is a combination of multicultural characteristics. It is not monocultural, it reflects specific multicultural reality. University broadcasts more than one culture, and its peculiarity is that it translates the multicultural reality of the individual making personality ascent to cultural values. Multicultural education in higher education should be aimed at creating conditions for overcoming barriers in communication and development of students from different ethnic and cultural groups (Bakhov, 2014).

The introduction of multicultural education in higher education institutions has taken various forms depending on the historical, social, economic, political conditions of the country. The legal aspect of multicultural education is based on legislation acts and documents: the Constitution of Ukraine, Laws "On national minorities in Ukraine", "On freedom of conscience and religious organizations", "On the protection of childhood", "On the prevention of violence in family", "On citizens' associations", the National Doctrine of Education Development in Ukraine and other valid documents.

There is a wide range of opinions and judgments concerning the concept of multicultural education. Hence, there is not a single term to denote the concept of "multicultural education". There exists a number of synonyms determining the above-mentioned phenomenon. For instance, "multicultural education", "intercultural education", crosscutural education.

The research shows that general principles of educational institutions for the development of multicultural education in Ukraine are as follows: openness of the national education system built on the dialogue of cultures; consideration of Ukrainian specific processes of inter-and intraethnic integration, ethno-cultural characteristics of each nation and ethnic group; fostering respect for national values and peculiarities of the Ukrainian language, way of life, traditions, religion; developing students' ability to adapt to a multicultural and multi-ethnic environment.

The main tasks of the multicultural education include the development of cultural diversity ideas; proper understanding of cultural values, formation of the students' positive attitude towards cultural differences, overcoming negative ethnic and social stereotypes; formation of the international communicative culture.

Multilingual education which is based on parallel teaching of three or more languages provides access to the dialogue of worldviews and cultures. Thus, multicultural and multilingual education is necessary for the formation of a competitive teacher capable of active and effective life in a multiethnic and multicultural environment with the understanding and respect for other cultures and the ability to live in peace and harmony.

Teaching foreign languages and foreign language culture greatly contributes to the formation of students' ability to communicate, coexist with people of different ethnic groups, form the rich experience of socio-cultural communication.

Teachers should help students in the formation and development of multicultural competence based on empathy and tolerant attitude towards others.

Ukraine, being a multicultural society, has to develop a new worldview aimed at the integration of cultures and peoples in order to further their rapprochement and spiritual enrichment. In connection 
with this, the level of requirements of modern society to the professional, his ability to adapt to ever-changing living conditions increases. The needs of educational practice give rise to the need for multicultural teacher training. We believe that to comprehensively study the phenomenon of multicultural education and determine the role of multicultural environment in the education system, it is advisable to refer to the understanding of the concept of culture competence approach.

Cultures contain many subcultures, which are sometimes defined by ethnicity, age, gender, disability. Cultural differences also arise from differences in social and economic or educational backgrounds. Students sense of belonging to a cultural group depends on how schools, media and other relevant sources transmit that culture top them.

The main purpose of the competence approach in studying a foreign language in the institution of higher education involves forming the whole personality of the student, his theoretical thinking, language intuition and skills, mastering the culture of speech communication and behavior that helps him to be an equal partner during intercultural communication in the Ukrainian language in everyday life, social, cultural and educational professional spheres. Personal and oriented approach during polycultural competence development includes the personality formation, concentrating on the necessity of creating truly comfortable, non-conflict and safe conditions for its development and realization of innate abilities.

Activity approach in foreign students' studying includes studying reorientation from the traditional mastering particular knowledge to the process of their receipt and functioning; formation of the main activity forms: communication, cognitive and educational activity; with their correlation and priority changing during studying; purposeful formation of the main abilities and skills and mental operations on basis of staged training.

Therefore, the multicultural education addresses the complex issues of teaching students with varying background, different cultural values, and multidimensional connections to various cultural subgroups. Knowledge of cultural differences can improve teachers' attitudes towards some students and change their expectations. Knowledge of how children acquire language will help teachers determine what characteristics the learning environment should have to help students learn the language in informal ways. It can also guide teachers in developing classroom activities appropriate for students at various stages of language development.

In order to promote multicultural understanding teachers should make students aware of the contributions that specific ethnic groups have made to the development of the country and the world, encourage students to identify themselves with the representatives of their ethnic group.

Conclusions. Taking into account the above-stated, it can be concluded that multicultural education is recognized as a priority because it is based on principles of tolerance, acceptance others and peaceful coexistence in a multicultural community. However, there are many problems connected with intercultural interaction such as the relationship between people with national and religious differences and geographical origin.

However, Ukraine has definite prospects for making a multicultural society based on mutual respect and harmony, although it is sometimes threatened by internal factors of the national and regional nature. This is primarily facilitated by various multicultural education activities being massively implemented in higher educational institutions.

The multicultural education is currently regarded as a foundation for the innovative pedagogical practice of equality and justice, is also believed to encourage them to continue self-cognition of their own ethnical and cultural identity as well as constant development of their own personality as representative of a particular social or ethnical group.

In fact, according to the contemporary pedagogical strategies multicultural education should be focused on absolutely all students, including representatives of the ethnic minorities or majorities; it is also focused on gaining mutual understanding and cultural exchanges, elimination of barriers related to the cultural tensions by means of introducing certain principles of teaching students.

The adoption of the polycultural education does not imply the destruction of the existing and functioning education system but contributes to its improvement by introducing new distinguishing characteristics. Polycultural education should become the basis of the education system of European countries and ought to be implemented for the sake of dialogue of cultures, tolerance and multilingual education. Polycultural education can no doubt ensure the relevance of the Ukrainian education system to modern social challenges. 


\section{BIBLIOGRAPHY}

1. Бахов І.С. Принципи і функції університетської полікультурної освіти. Інноваційні наукові технології : передовий світовий досвід : зб. наук. паць і матеріалів Міжнар. наук-практ. конф., 5 листопада 2012 р. Кіровоград : Науково-дослідний центр інноваційних технологій, 2012. С. 31-39.

2. Brown, H. Douglas. (2000). Principles of language learning and teaching. NY: Longman.

3. Intenational Dictionary of Education. London, Kogan Page., 1973, 273 p.

4. Intenational Encyclopedia of Education Vol. 7. Oxcford, Rergamon Press. 1994.

5. Ковалинська I.В. Поняття «полікультурність» та «мультикультурність» у науковому дискурсі. Ocвimoлогічний дискурс. 2016. № 1 (13). С. 65-78.

6. Кузьменко В.В., Гончаренко Л.А. Формування полікультурної компетентності вчителів загальноосвітньої школи : навчальний посібник. Херсон : РІПО, 2006. 92с.

7. Лощенова І.Ф. Полікультурне виховання майбутніх вчителів у процесі вивчення іноземних мов : дис. ... канд. пед. наук: 13.00.07. Київ, 2004. 176 с.

8. Nieto S. (2000) Affirming diversity: The sociopolitical context of multicultural education (3 rd ed.). New York : Longman. $449 \mathrm{p}$.

9. Taylor, E.W. (1994). Intercultural competency: A transformative learning process. Adult Education Quartely, 44 (3), pp.154-174.

\section{REFERANCES}

1. Bakhov, I. S. (2012). Pryntsypy i funktsii universytetskoi polikulturnoi osvity [Principles and functions of the university polycultural education]. Innovatsiini naukovi tekhnolohii: peredovyi svitovyi dosvid: $\mathrm{zb}$. nauk. pats i materialiv Mizhnar. nauk-prakt. konf., 5 lystopada 2012 r. Kirovohrad: Naukovo-doslidnyi tsentr innovatsiinykh tekhnolohii, 31-39 [in Ukrainian].

2. Brown, H. Douglas. (2000). Principles of language learning and teaching. NY : Longman

3. Intenational Dictionary of Education (1977). London, Kogan Page., 273

4. Intenational Encyclopedia of Education (1994). Vol. 7. Oxcford, Rergamon Press.

5. Kovalynska I.V. (2016). Poniattia "polikulturnist" ta "multykulturnist" u naukovomu dyskursi [The concept of polyculturalism and multiculturalism in the scientific discourse]. Osvitolohichnyi dyskurs, 1 (13), 65-78 [in Ukrainian].

6. Kuzmenko V.V., Honcharenko L.A. (2006) Formuvannia polikulturnoi kompetentnosti vchyteliv zahalnoosvitnoi shkoly [Multicultural competence formation of the secondary school teachers] : navchalnyi posibnyk. Kherson : RIPO, $92 \mathrm{~s}$. [in Ukrainian].

7. Loshchenova I. F. (2004) Polikulturne vykhovannia maibutnikh vchyteliv u protsesi vyvchennia inozemnykh [movmulticultural education of future teachers in the process of learning foreign languages]: dys. ... kand. ped. nauk: 13.00.07. Kyiv, 176 p. [in Ukrainian].

8. Nieto S. (2000) Affirming diversity: The sociopolitical context of multicultural education (3 $\mathrm{rd}$ ed.). New York : Longman. $449 \mathrm{p}$.

9. Taylor, E.W. (1994). Intercultural competency: A transformative learning process. Adult Education Quartely, 44 (3), 154-174

Стаття надійшла до редакиї 27.05.2021 